\title{
Does Education Level Matter in Women's Risk of Early Marriage?: Case Study in Rural Area in Indonesia
}

\author{
Agung Dwi Laksono ${ }^{1}$, Ratna Dwi Wulandari ${ }^{2}$, Ratu Matahari ${ }^{3}$ \\ ${ }^{1}$ Rsesearcher, National Institute of Health Research and Development, the Indonesia Ministry of Health, Jakarta, \\ Indonesia, ${ }^{2}$ Researcher, Faculty of Public Health, Universitas Airlangga, Surabaya, Indonesia, ${ }^{3}$ Researcher, \\ Faculty of Public Health, Universitas Ahmad Dahlan, Yogyakarta, Indonesia
}

\begin{abstract}
Several studies inform that early marriage is correlated with several situations, including socioeconomic status, cultural wisdom, religious values, education, and internet access. The study was aimed at analyzing the effect of education level on women's risk of early marriage in rural areas in Indonesia. The study used data from the 2017 Indonesian Demographic and Health Survey. There were 2,252 women aged 19-24 years in a rural area in Indonesia who was taken as a sample. The variables analyzed included early marriage, education level, wealth status, and employment status. The final stage was used as a binary logistic regression test to determine the risk factors. The result found that women who have secondary education have a risk of 0.396 times compared to women who have primary education to experience an early marriage (OR 0.396; 95\% CI 0.309-0.506). Women who have a higher education have a risk of 0.091 times compared to women who have primary education to experience an early marriage (OR $0.091 ; 95 \%$ CI $0.059-0.140$ ). This finding informs that the education level was a determinant of the incidence of early marriage among women in rural Indonesia. The lower the education of a woman in a rural area, the higher the risk of experiencing an early marriage. It could be concluded that a low level of education is a risk factor for women's early marriage in rural areas in Indonesia.
\end{abstract}

Keywords: Education level, early marriage, maternal health, reproductive health.

\section{Introduction}

Early marriage is a phenomenon related to socioeconomic conditions in developing countries. Early marriage can also be interpreted as child marriage. This phenomenon is increasing in number from year to year so that it becomes the focus of the target of the 5 th point of the Sustainable Development Goals ${ }^{1}$. The prevalence rate of early marriage in Indonesia is high. The 2018 National Economic Survey (Susenas) noted that there were around 1.2 million adolescents who married before the age of $18^{2}$. The Indonesia Demographic and Health Survey $2002-2017$ reported that $10 \%$ of Indonesian women became pregnant before the age of $18^{3}$. Moreover, the Indonesian government is also targeting a reduction in the prevalence of early marriage from $11.2 \%$ in 2018 to $8.74 \%$ in 2024 through the $2020-2024$ National Medium Term Development Plan (RPJMN) so that by 2030 it can be targeted that the rate of early marriage is at $6.94 \%{ }^{2}$.
Early marriage in Indonesia is a common thing, given that marriage in traditional culture is part of the family's responsibility, not an individual desire, so that the family plays an important role in determining a marriage compared to the wishes of the child ${ }^{4}$. Globally, Indonesia is a country with the largest Muslim majority population, so that socio-cultural conditions are closely related to religious values held by a person ${ }^{4,5}$. The social construction in Muslim societies makes early marriage defined as the act of preventing unlawful sexual acts among adolescents ${ }^{6,7}$. Besides, the concept of maintaining virginity until marriage takes place also underlies the occurrence of early marriage in Indonesia ${ }^{7}$.

Several studies have shown that early marriage is positively correlated with several situations, including socioeconomic status, cultural wisdom, religious values, education, and internet access ${ }^{8-10}$. In several regions in Indonesia, it has cultural values that support early marriage ${ }^{11,12}$. The social construction that is formed in 
this community is a shame if in a family there are teenage girls who do not get married, there is still a strong opinion that the education of boys is more important than girls, and marrying children in adolescence can help ease the economic burden family ${ }^{13-15}$

Early marriage is a complex social problem that can have physical and psychological consequences. Teenage girls are very vulnerable to maternal mortality, child mortality, miscarriage, and giving birth to babies with low birth weight because knowledge related to motherhood is still very minimal, and reproductive organs are not ready to get pregnant and give birth ${ }^{5}$. Another impact is young women faced with conditions of dropping out of school, anxiety, victims of domestic violence, to the trauma of living life ${ }^{10}$. Seeing the wide impact of early marriage on young women, it is very important to equip adolescents with knowledge about reproductive health, including the long-term consequences of early marriage. Young women are still allowed to go to school as an alternative to improve the quality of life of young women so that they can compete for jobs and better livelihoods ${ }^{6}$.

Based on the background description, this study was aimed at analyzing the effect of education level on women's risk of early marriage in rural areas in Indonesia. The results of this study are considered important for population policymakers to provide clear policy targets to reduce the rate of early marriage in Indonesia.

\section{Materials and Method}

Data Source: The study uses data sourced from the 2017 Indonesia Demographic and Health Survey (IDHS). The 2017 IDHS sample was taken using the stratification and multistage random sampling method. The unit of analysis for women aged 19-24 in rural Indonesia. Selection of the unit of analysis for women at $\leq 19$ years of age because they had passed the age limit for early marriage. While the age limit is less than $\leq 24$ years old, assuming there is no significant change in the demographic characteristics of the respondents to be tested to be a determinant of the incidence of early marriage. With the analysis unit, a sample size of 2,252 women in rural areas of Indonesia was obtained.

Data Analysis: In this study, the definition of early marriage is a marriage that is done before the age of 19 years old. This age limit refers to Law 16 of 2019 concerning Amendments to Law 1 of 1974 concerning Marriage. The independent variables analyzed in this study were education level, wealth status, and employment status.

Analysis at the initial stage was carried out using chisquare to determine the relationship between variables. Determination of risk factors is carried out using a binary logistic regression test because of the nature of the dependent variable. All statistical tests were carried out with the help of SPSS type 22.

\section{Results and Discussion}

Table 1. Descriptive statistics of education level and individual characteristics of the respondent $(n=2,252)$

\begin{tabular}{|c|c|c|c|c|c|c|c|}
\hline \multirow{3}{*}{ Characteristics } & \multicolumn{6}{|c|}{ Education Level } & \multirow{3}{*}{$\mathbf{p}$} \\
\hline & \multicolumn{2}{|c|}{ Primary } & \multicolumn{2}{|c|}{ Secondary } & \multicolumn{2}{|c|}{ Higher } & \\
\hline & $\mathbf{n}$ & $\%$ & $\mathbf{n}$ & $\%$ & $\mathbf{n}$ & $\%$ & \\
\hline Early marriage & & & & & & & $* * *<0.001$ \\
\hline No & 96 & $15.7 \%$ & 516 & $34.4 \%$ & 101 & $70.6 \%$ & \\
\hline Yes & 514 & $84.3 \%$ & 983 & $65.6 \%$ & 42 & $29.4 \%$ & \\
\hline Wealth status & & & & & & & $* * *<0.001$ \\
\hline Poorest & 406 & $66.6 \%$ & 687 & $45.8 \%$ & 48 & $33.6 \%$ & \\
\hline Poorer & 119 & $19.5 \%$ & 394 & $26.3 \%$ & 26 & $18.2 \%$ & \\
\hline Middle & 59 & $9.7 \%$ & 252 & $16.8 \%$ & 27 & $18.9 \%$ & \\
\hline Richer & 19 & $3.1 \%$ & 115 & $7.7 \%$ & 21 & $14.7 \%$ & \\
\hline Richest & 7 & $1.1 \%$ & 51 & $3.4 \%$ & 21 & $14.7 \%$ & \\
\hline Employment status & & & & & & & $* * 0.002$ \\
\hline Unemployed & 387 & $63.4 \%$ & 1055 & $70.4 \%$ & 88 & $61.5 \%$ & \\
\hline Employed & 223 & $36.6 \%$ & 444 & $29.6 \%$ & 55 & $38.5 \%$ & \\
\hline
\end{tabular}

Note: ${ }^{*} \mathrm{p}<0.05 ;{ }^{*} \mathrm{p}<0.01 ;{ }^{* * *} \mathrm{p}<0.001$. 
Table 1 provides descriptive statistics of the education level and individual characteristics of the respondent. It can be seen that early marriage is more dominant in women who have primary and secondary education. Based on wealth status, it can be seen that all categories of education level are dominated by the poorest women. Meanwhile base on employment status, it can be seen that all categories of education level are dominated by unemployed women.

Table 2 shows the results of binary logistic regression of early marriage among women in rural areas in Indonesia. Women who have secondary education have a risk of 0.396 times compared to women who have primary education to experience an early marriage (OR 0.396; 95\% CI 0.309-0.506). Women who have a higher education have a risk of 0.091 times compared to women who have primary education to experience an early marriage (OR 0.091; 95\% CI 0.059-0.140). These findings inform that education level is a determinant of early marriage among women in rural areas in Indonesia. The lower the education of a woman in a rural area, the higher the risk of experiencing an early marriage.Low education is probably closely related to an understanding of the risks of early marriage which is also low ${ }^{16,17}$.

A study in Iran found that apart from the level of education, there are other factors related to education that are also a determinant of early marriage, namely the level of knowledge about the impacts of child marriage ${ }^{18}$. Several previous studies have informed that education is a positive determinant of performance output in the health sector ${ }^{19-21}$. Furthermore, low education is informed as a barrier to performance output in the health sector $^{22,23}$.

Table 2. The result of binary logistic regression of early marriage among women in rural area Indonesia $(n=2,252)$

\begin{tabular}{|l|c|c|c|c|}
\hline \multirow{2}{*}{ Predictors } & \multicolumn{4}{|c|}{ Early Marriage } \\
\cline { 2 - 5 } & Sig. & OR & Lower Bound & Upper Bound \\
\hline Education level: Primary & - & - & - & - \\
\hline Education level: Secondary & $* * *<0.001$ & 0.396 & 0.309 & 0.506 \\
\hline Education level: Higher & $* * *<0.001$ & 0.091 & 0.059 & 0.140 \\
\hline Wealth status: Poorest & - & - & - & - \\
\hline Wealth status: Poorer & $* 0.032$ & 0.776 & 0.615 & 0.978 \\
\hline Wealth status: Middle & $* * 0.001$ & 0.639 & 0.489 & 0.834 \\
\hline Wealth status: Richer & $* * *<0.001$ & 0.434 & 0.303 & 0.620 \\
\hline Wealth status: Richest & $* 0.045$ & 0.603 & 0.368 & 0.988 \\
\hline Employment status: Unemployed & - & - & - & - \\
\hline Employment status: Employed & $* 0.014$ & 1.294 & 1.054 & 1.588 \\
\hline
\end{tabular}

Note: $* \mathrm{p}<0.05 ; * * \mathrm{p}<0.01 ; * * \mathrm{p}<0.001$.

Women who have the wealth status of the poorer category have a risk of 0.776 times compared to the poorest women to experience an early marriage (OR 0.776; 95\% CI 0.615-0.978). Women who have wealth status in the middle category have a risk of 0.639 times compared to the poorest women to experience an early marriage (OR 639; 95\% CI 0.489-0.834). Women who have wealth status in the richer category have a risk of 0.434 times compared to the poorest women to experience an early marriage incident (OR 0.434; 95\%
CI 0.303-0.620). The richest women had a risk of 0.603 times compared to the poorest women to experience an early marriage incident (OR 0.603 ; 95\% CI 0.368 0.988 ). This finding informs that poverty is a risk factor for early marriage among women in rural Indonesia.

Previous studies in various developing countries have found similar results that poverty is a risk factor for early marriage. Some of these countries are in South Sudan, Bangladesh, and India ${ }^{24-27}$. In the context in Indonesia, the phenomenon of early marriage tends to 
occur in poor families of women. Early marriage is one practical way for poor families to get out of poverty. Marrying a girl from a poor family to a rich male family is a shortcut to a better life ${ }^{28,29}$ with girls constituting the majority (76 per cent.

Finally, employed women have 1.294 times the risk of unemployed women experiencing an early marriage (OR 1.294; 95\% CI 1.054-1.588). The results of this analysis inform that employed is a risk factor for early marriage among women in rural Indonesia. The employment status of women is closely related to the wealth status of the family. In developing countries, women tend to be responsible for domestic affairs. If women take part in earning a living, especially in non-formal manual labor, they often come from poor families ${ }^{30-32}$.

\section{Conclusions}

Based on the results of the analysis, it was found that low-level education is a risk factor for women's early marriage in rural areas in Indonesia. Two other variables that were also found as risk factors were low wealth status (poor) and employed.

These findings provide clear information on targets for the government to reduce the incidence of early marriage in Indonesia. It is recommended that the government set targets that focus on those with low levels of education and the poor for policies to reduce the incidence of early marriage in Indonesia.

\section{Source of Funding: Self-funding}

Conflict of Interest: The authors declare no conflict of interest, financial or otherwise.

Ethical Clearance: The 2017 IDHS has received ethical approval from the National Ethics Committee. All respondent identities have been deleted from the dataset. Respondents have signed and agreed to their involvement in the 2017 IDHS. Utilization of 2017 IDHS data for this research has received permission from ICF through the website: https://dhsprogram.com/ data/new-user-registration.cfm.

\section{References}

1. Unicef Indonesia. Saying No to Child Marriage in Indonesia. 2020.

2. UNFPA. Government of Indonesia Commits to End Child Marriage. 2020. p. 5-7.
3. BKKBN. Survei Demografi dan Kesehatan Indonesia. 2017.

4. Widyastari DA, Isarabhakdi P, Shaluhiyah Z. Intergenerational patterns of early marriage and childbearing in Rural Central Java, Indonesia. J Popul Soc Stud. 2020;28(3):254-60.

5. Rahman RTA, Yuandari E. Early Marriage in Banjarmasin: The Impact on Reproductive Health and Prevention Strategy. Int J Clin Invent Med Sci. 2020;2(1):15-9.

6. Widyastari DA. Revisiting the New Indonesia's Marriage Act 2019 : will it be effective to prevent adolescent marriage? INSIGHTS Public Heal J. 2019;1(1).

7. Martin-Anatias N. On Being a "Good" Indonesian Muslim Woman: An Autoethnography. Humanity Soc. 2019;43(4):351-74.

8. Ningsih AP, Muis M, Syafar M, Abdullah MT. Adolescent' s P erception and Severity Related to Early Marriage, in Selayar Island. Int J Multicult Multireligious Underst. 2020;7(4):132-9.

9. Rahayu WD, Wahyuni, Ph.D. H. the Influence of Early Marriage on Monetary Poverty in Indonesia. J Indones Econ Bus. 2020;35(1):30-43.

10. Velentza C. Early Marriage and Education Drop Out in Traditional Roma Communities in Transylvania. J Gypsy Stud. 2020;2(1):39-54.

11. Pratiwi NL, Fitrianti Y, Nuraini S, Rachmawati T, Laksono AD, Afreni M, et al. Concealed Pregnant Women or Kemel of Gayo Ethnic in Blang Pegayon District, Gayo Lues District, Aceh. Bull Heal Syst Res. 2019;22(2):81-90.

12. Laksono AD, Faizin K, Raunsay EM, Soerachman R. Muyu women in exile (Perempuan Muyu dalam Pengasingan) [Internet]. Jakarta: Lembaga Penerbitan Balitbangkes; 2014. Available from: https://www.scribd.com/doc/261673624/ Perempuan-Muyu-dalam-Pengasingan-RisetEthnografi-Kesehatan-2014-Boven-Digoel

13. Laksono AD, Wulandari RD. "Children are Assets": Meta Synthesis of Child Values in the Lani and Acehnese ("Anak adalah Aset": Meta Sintesis Nilai Anak pada Suku Lani dan Suku Aceh). J Kesehat Reproduksi. 2019;10(1):11-20.

14. Jones GW. Which Indonesian women marry youngest, and why? J Southeast Asian Stud. 2001;32(1):67-78. 
15. Grijns M, Horii H. Child Marriage in a Village in West Java (Indonesia): Compromises between Legal Obligations and Religious Concerns. Asian J Law Soc. 2018;5(2):453-66.

16. Trommlerová SK. When children have children: The effects of child marriages and teenage pregnancies on early childhood mortality in Bangladesh. Econ Hum Biol. 2020;39:Article number 100904.

17. Chauhan S, Sekher TV, Kumar P, Srivastava S, Patel R. Prevalence, determinants and socioeconomic inequality of early marriage among men in India. Child Youth Serv Rev. 2020;116:Article number 105273.

18. Heidari F, Dastgiri S. The prevalence and predicting factors of female child marriage in north-west of iran: A case-control multi-center study. Gazi Med J. 2020;31(3):387-92.

19. Wulandari RD, Laksono AD. Education as predictor of the knowledge of pregnancy danger signs in Rural Indonesia. Int J Innov Creat Chang. 2020;13(1):1037-51.

20. Wulandari RD, Laksono AD. Determinants of knowledge of pregnancy danger signs in Indonesia. PLoS One. 2020;15(5):Article number e0232550.

21. Ipa $M$, Widawati $M$, Laksono $A D$, Kusrini I, Dhewantara PW. Variation of preventive practices and its association with malaria infection in eastern Indonesia: Findings from community-based survey. PLoS One. 2020;15(5):e0232909.

22. Laksono AD, Wulandari RD. The Barrier to Maternity Care in Rural Indonesia. J Public Heal From Theory to Pract. 2020; Online First.

23. Rohmah N, Yusuf A, Hargono R, Laksono AD, Masruroh, Ibrahim I, et al. Determinants of teenage pregnancy in Indonesia. Indian J Forensic Med Toxicol. 2020;14(3):2080-5.
24. Madut KK. Determinants of Early Marriage and Construction of Gender Roles in South Sudan. SAGE Open. 10(2).

25. Razu SR. Determinants of early marriage among women: An experience from rural Bangladesh. Gend Stud. 2018;17(1):127-36.

26. Talukder A, Hasan MM, Razu SR, Hossain MZ. Early marriage in Bangladesh: A cross-sectional study exploring the associated factors. J Int Womens Stud. 2020;21(1):68-78.

27. Paul P. Effects of education and poverty on the prevalence of girl child marriage in India: A district-level analysis. Child Youth Serv Rev. 2019;100:16-21.

28. Singh R, Vennam U. Factors Shaping Trajectories to Early marriage : Evidence from Young Lives, India. Young Lives Working Paper 149. 2016.

29. Muharry A, Hakimi M, Wahyuni B. Family Structure and Early Marriage on Women in Indramayu Regency. J Kesehat Masy. 2018;13(3):314-22.

30. Kohno A, Dahlui M, Nik Farid ND, Ali SH, Nakayama T. In-depth examination of issues surrounding the reasons for child marriage in Kelantan, Malaysia: A qualitative study. BMJ Open. 2019;9(9):Article number e27377.

31. Kohno A, Dahlui M, Nik Farid ND, Safii R, Nakayama T. Why girls get married early in Sarawak, Malaysia - An exploratory qualitative study. BMC Womens Health. 2020;20(1):Article number 46.

32. Keskiner E. Marriage decisions of Turkish secondgeneration women in Strasbourg: not a fate but a refuge. Ethn Racial Stud. 2020;43(16):231-48. 